\title{
Halal Foods Purchase Intension among Indonesian Non-Muslim Consumers: An Exploratory Case Study Approach
}

\author{
Agus Purwanto* ${ }^{1}$, Masduki Asbari ${ }^{2}$, Priyono Budi Santoso ${ }^{3}$, Laksmi Mayesti Wijayanti ${ }^{4}$, \\ Choi Chi Hyun ${ }^{5}$, Rudy Pramono ${ }^{6}$ \\ ${ }^{*}$ Doctoral of Management, Pelita Harapan University \\ Karawaci, Tangerang, Indonesia
}

\begin{abstract}
The aim of this research was to identify and investigate the awareness of non moslem consumers as respondents in Indonesia to buy halal-labeled food products. Research on consumer awareness of intention to purchase halal-labeled food products is still inadequate in Indonesia. This research uses a qualitative method that is an explorative case study. Primary data collection uses a semi-structured interview with 10 (ten) of nonMuslim consumers in Indoenesia who have been determined using purposive sampling method. The results of this research show that majority of respondents have a positive awareness of halal labeled foods, including their benefits and food processing production process. This study can be concluded that the majority of nonMuslim consumer respondents already have good knowledge, understanding and perception of halal food packaging that is safe, hygienic, clean, is produced in a clean and guaranteed quality. Most non-Muslim consumer respondents also have a high interest in buying and consuming packaged food products labeled as halal
\end{abstract}

Keywords - Purchase Intentions, Halal Awareness, Halal Food Products

\section{INTRODUCTION}

Indonesia is in the first position of 10 countries with the largest amount of halal food expenditure in the world. Overall, halal food consumption of the world's population reached 1,303 billion US dollars throughout 2017. The figure will increase 6.1 percent in coming 2023, namely reaching 1,863 billion US dollars in 2023. It would be very unfortunate, if Indonesia with such great potential with the largest population in the world is only satisfied with being country with the largest amount of halal food consumption in the world. Indonesia as the largest Muslim country representing 13 percent of the global Muslim population, is an integral and central part of an increasingly large Muslim economy throughout the world. Approximately 218.8 billion US dollars spent by Indonesian Muslims in all sectors of the Islamic economy in 2017. Indonesia is considered to have the opportunity to become producers in the halal industry not just to become consumers. This is supported by its Muslim population where as many as 207 million or 87.2 percent of Indonesia's population are Muslims. This figure gives Indonesia the title of country with the largest Muslim population in the world. In the list of 10 countries with the best halal food industry climate, there is United Arab Emirates in the first position, then followed by Malaysia, Brazil, Oman, Jordan, and Australia. Then there are also Brunei Darussalam, Pakistan, Sudan and Qatar. The following is a list of countries with the largest halal food expenditure in the world based on 2018/2019 Global Islamic Economy Report data. Indonesia: 170 billion US dollars Turkey: 127 billion US dollars Pakistan: 118 billion US dollars Egypt: 86 billion US dollars Bangladesh: 76 billion US dollars Iran: 63 billion US dollars Saudi Arabia: 51 billion US dollars Nigeria: 47 billion US dollars Russia : 41 billion US dollars India: 38 billion US dollars.

The level of consumption of the global Muslim community as a whole is estimated at US \$ 1.9 trillion, of which 89 percent or US $\$ 1.7$ trillion is used to consume food and beverage products. Cconsumption level is expected to increase 2 times more than US \$ 3 trillion in 2021 with food and beverage consumption of US \$ 1.9 trillion (compound growth rate of 8.5 percent). Indonesia has a large potential market for halal products because it has a Muslim majority population, which is 207 million people or 87 percent of the total population. This condition is supported by opportunities for non-Muslim consumers to demand halal products so that it is possible to capitalize halal products. Rosalani (2016) from the Indonesian Chamber of Commerce explained that 
in 2014, the market value of halal products reached US \$ 2.3 trillion and the figure was projected to increase to US \$ 3.7 trillion in 2019. However, Indonesia's halal food and beverage industry was still far behind that of nonMuslim countries such as Australia and Brazil. In addition, there are still many outstanding non-halal certified products offered to Muslim consumers as the majority of population. In 2011, only 36.73 percent of 113515 registered products or only 41695 food products, medicines and cosmetics in Indonesia were halal-certified.

Some packaged food products in circulation do not yet have a halal certificate nationally. This condition is caused by the loosening of halal protection. Halal certificates do not yet have legal legitimacy because inclusion of halal marks is not an obligation regulated by law, but is based on voluntary initiatives from business actors for presentation of their products. Several factors influence awareness of halal (awereness) from consumers which in turn influences demand for halal products (purchase intention). Some of these factors are: religiosity (religious believe), identity (self identity), and halal guarantee labels (halal certification). Awareness (awereness) is defined as an understanding of the halal nature of a product from a consumer so as to make it careful in making consumption of a product, while purchase intention is tendency of consumers to buy something or an action related to buying and is measured by the level of purchase return the product.

The purpose of this study was to explore and investigate the level of awareness among respondents regarding purchase of halal food products in Indonesia. This is because the level of awareness of non-Muslim consumers towards intention to purchase halal food products will obviously be different from Muslim consumers who live in same area in Indonesia. However, the current research has four main objectives. The first objective of this study was to identify the level of awareness of respondents about halal labeled food products. The second objective is to explore respondents' awareness regarding processes involved in making halal labeled food products. The third objective is to explore respondents' awareness regarding benefits of halal food products. The fourth objective is to identify the importance of conducting exploratory studies of respondents to purchase halallabeled food products. Thus, the following research questions are posed:

\section{Definition of Halal}

\section{LITERATURE REVIEW}

The word halal comes from Arabic and is usually used to refer to permits or halal (Khan and Haleem, 2016; Wilson and Liu, 2010). Halal is a word in the Koran and shows validity of actions or permitted consumption of something (Elasrag, 2016). On the other hand, the word for haram or non-halal also means prohibited, and is usually used to signify things that may not be consumed or involved by a Muslim (Abdul-Razzaq, 2016; Elasrag, 2016)]. Halal is a general term, which covers all aspects of Muslim life and all types of food. In addition, halal is not only related to food or food products but also further from food products to cover all aspects of a Muslim's personal life (Khan and Haleem, 2016; Majid et al., 2015). Halal as a hallmark of Islam forms a key stage from global power, therefore, cannot be neutered or ignored (Wilson and Liu, 2011). Halal is not only a characteristic component of identity for Muslims but also part of a belief system and moral code of ethics, which is related to daily life (Wilson and Liu, 2010).

\section{Halal Food Products}

Halal food and beverages are the main sectors among the global halal industry. Halal in the food and beverage sector is distinguished and has attracted more investors and entrepreneurs around the world (Ali, 2018). Global market for halal food is growing triggering curiosity among respondents regarding consumption of halal food products (Krishnan et al., 2017). This is because Muslim minorities in non-Muslim countries are demanding halal food products and growing awareness potential of the global halal food market. It could also be because consumers are becoming more and more realize that halal food products are potentially healthier, safer, hygienic and are produced using clean facilities that make halal products increasingly popular (Teng et al., 2013). In addition, respondents bought halal-labeled food because they considered it a healthy food product and because of their concerns about food safety (Teng and WanJusoh, 2017). Healthy halal food product for human consumption because of how it was prepared and processed (Ismoyowati, 2015). Concept of halal food represents cleanliness, purity and quality of food consumed (Mathew et al., 2014; Haque et al., 2015). Another study found that there was a positive response to halal food that was healthy, safe, clean, tasty and quality (Golnaz et al., 2012; Azizdan Chok, 2013; Haque et al., 2015). A similar study conducted by Abdullah (2006), Mathew et al. (2014) found that consumers are more aware about the food they consume, especially, in relation to health, sources, cleanliness and quality. According to Farm and Jacoby (2005), consumers demand fresh and 
authentic qualities because of their concern about food safety, nutrition and finding out where they come from and how they are produced. Thus, the level of awareness is the most important factor influencing consumers' choices to buy halal food products (Hamdan et al., 2013). A study conducted by Yang and Huang (2017) also shows that consumer awareness of halal-labeled food products has a significant impact on the buying behavior of non-Muslim consumers. This is because the success rate of halal food industry is determined by consumers halal awareness (Mohamed et al., 2013).

\section{Halal Awareness}

Awareness generally refers to understanding and information about certain things (Aziz and Chok, 2013). This is a fundamental factor in finding information for halal food. Awareness of halal food products plays a key role in improving halal food in the industry (Mohamed et al., 2013). Awareness has a direct influence on purchasing behavior, decision making to buy halal food products (Bashir et al., 2018). Krishnan et al. (2017) explain the awareness of people who by purchasing halal food, they find that Muslim consumers choose halal food because they know that it is mandatory for them. After this, Muslim consumer behavior refers to obligation to consume halal food (Wilson and Liu, 2011). On the other hand, Muslim consumers consume halal because of its health benefits and not because of religious observances. Zakaria et al. (2017) found that there was a positive relationship between halal awareness and religiosity on consumer intentions to buy halal-certified food products. Other research conducted by (Abd Rahman et al., 2015; Aziz and Chok, 2013; Hamdan et al., 2013), also emphasizes that awareness has a positive effect on consumers' attitudes towards purchasing halal food products. Therefore, Aziz and Chok (2013) emphasize that halal awareness has an influence in explaining intention to buy halal products. Hamdan et al. (2013) revealed that the most influential factor in choice of Muslim consumers to buy halal food was the level of product knowledge. This means that, if there is an increase in Muslim consumer awareness about halal, there will be an increase in demand for halal food products that they want to buy (Elasrag, 2016). According to Macdonald and Sharp (2000) found that awareness is a rule of thumb adopted by consumers when making purchasing decisions, if they have greater awareness that the food product meets halal requirements, they will show greater purchase intention to buy halal food. Mohamed Elias et al. (2016) revealed that the majority of consumers have a positive relationship between awareness, knowledge and economy of intentions and behavior of producing halal food products. Similarly, research conducted by Aziz and Chok (2013) provides evidence of a significant relationship between halal awareness and other elements with intention of purchasing halal food among respondents in Malaysia.

\section{Non-Muslim Consumers}

Some previous studies have revealed that apart from Muslim consumers, respondents are also interested in consuming food products labeled as halal, because they have an opinion that halal food is cleaner, safer, healthier and of better quality (Rezai et al., 2012; Aziz and Chok , 2013). According to Wibowo and Ahmad (2016), there is a need for additional research on respondents' problems in halal industry for empirical and nonempirical studies. Respondents turned to halal-labeled food due to increased concerns about contaminated and unhealthy foods (Zailani, Kanapathy et al., 2015). Previous research (Abdullah, 2006; Golnaz et al., 2010) found that non-Muslims view halal food positively where they believe that halal food products are healthy, handled and prepared and produced hygienically. Along with this, empirical research is conducted by Golnaz et al. (2010) found that respondents were aware of existence of halal principles and benefits of the halal process, especially in animal slaughter methods, while other studies showed a high percentage of halal awareness among respondents (Golnaz). et al., 2012). Teng and Wan Jusoh (2017) also suggest that respondents 'shopping behavior is related to several demographic factors related to fair trade, animal welfare, understanding halal concepts and intentions. From some of literature above, there is not much research on respondents' awareness about halal food products in Indonesia. Therefore, this research is an attempt to fill this knowledge gap in the halal awareness literature in Indonesia.

\section{METHODS}

The study uses exploratory case study methods and the research approach uses qualitative case study methods which are used to gain an understanding of the level of awareness of respondents in Indonesia. Sample size is based on achieving depth and wealth description, not sample size. According to Guetterman (2015), sample size is not a matter of representative opinion and views, but rather a matter of information wealth. In this study, researchers were involved in an intensive focus on several participants (Frost, 2011). For confidentiality purposes, responders are given initials R1, R2, R3, R4, R5, R6,R7, R8, R9 and R10 Semi-structured interviews 
were conducted and a list of questions was arranged for interviews developed based on the related literature. Respondents for this study are Muslim consumers of halal-labeled food who live in Indonesia. Consumers who more and more often buy and consume halal-labeled foods are invited to take part in this research.

Table 1. Profile of Non Muslims Respondents

\begin{tabular}{|l|l|l|l|l|}
\hline Initial & Gender & Age & Status & Education \\
\hline R1 & Women & 24 & Single & Diploma \\
\hline R2 & Male & 35 & Married & Bachelor Degree \\
\hline R3 & Women & 46 & Married & Bachelor Degree \\
\hline R4 & Male & 35 & Single & Diploma \\
\hline R5 & Women & 24 & Single & Diploma \\
\hline R6 & Male & 35 & Married & Bachelor Degree \\
\hline R7 & Women & 56 & Married & Bachelor Degree \\
\hline R8 & Male & 33 & Single & Diploma \\
\hline R9 & Women & 43 & Married & Bachelor Degree \\
\hline R10 & Male & 24 & Single & Diploma \\
\hline
\end{tabular}

The primary collection method is with semi-structured interviews while secondary data is collected from published data such as journal articles and books. This study is limited to the sample size of four respondents living in Indonesia City. This research is an exploratory case study and the sample was selected using purposive sampling method. In qualitative research, a purposive sampling technique is a method used to achieve certain research objectives. There is no limit to the number of respondents to make a purposive sample, provided desired information can be obtained and generated (Bernard, 2002). To conduct case study research, Creswell (2013) provides observations and several sample size recommendations, which range from no more than four to five cases. In case study the respondents were interviewed until data saturation was reached and no new information could be obtained (Guest et al., 2006; Krysik and Finn, 2010). All respondents provided information sheets before interview. Interview place is conducted in a location that is convenient for the respondents. All interviews, with permission and consent signed, were recorded audio and then verbally transcribed.

Analysis and interpretation of data is the most critical part of qualitative research. Thematic data analysis guidelines (Creswell, 2009) are used. This is considered the most appropriate for any research that seeks to explore several interpretations (Alhojailan, 2012). In the thematic analysis "all possible interpretations are possible" (Alhojailan, 2012, p. 10). The reason for choosing a thematic analysis is that "a rigorous thematic approach can produce in-depth analysis that answers certain research questions" (Braun and Clarke, 2006, p. 97). After a rigorous analysis, researchers describe the findings, according to four main themes. To measure the level of awareness of respondents about buying halal food products in Indonesia, a number of research questions were made, asked the following questions, do respondents halal, do respondents in know halal food products, do the respondent shave knowledge of processes involved in making halal food products, do the respondent understand the difference between halal and non-halal food products.

\section{RESULTS}

The purpose of this study was to identify the level of awareness of non-Muslim consumption towards purchase of halal packaged food products in Indonesia. All participants' responses are original quotes, and they have been quoted as stated by the respondents. In the interview, respondents were asked to explain about their awareness and understanding of halal.

\section{Non-Muslim Consumer Knowledge about Halal Food}

This shows that majority of respondents have an understanding of halal food and offer their perceptions. It also shows that respondents understand the health benefits associated with halal food products. 
$\mathrm{R}(6)$ "... halal food not contaminated from pigs ...."

$\mathrm{R}$ (7) ".. halal food is consumed for Muslims and non-Muslims .."

Some respondents have provided some comments and give statements as follows :

$\mathrm{R}(7)$ "... I believe halal products are not contaminated from hazardous materials ..."

$\mathrm{R}(5)$ "... is halal for Muslim obligations and is also good for non-Muslim consumption ..."

Other respondents explained their understanding of halal as follows:

"Something that is pork free. For me it's halal. If there is something that does not have pork and is ready to be prepared in an Islamic way then it is halal "(R1).

Some respondents also added a statement that:

"Actually, what I understand about halal food is pork free" (R1).

Some respondents have provided some comments and give statements as follows :

$\mathrm{R}(9)$ "... I think halal food does not contain ingredients from pigs ..."

R10) "... I believe halal food is for all consumers, not only for Muslims ...

These statements shows that majority of respondents attributed absence of pigs as a hallmark of halal food. Although it is not permissible for Muslims to consume pork, this does not mean that non-pork food automatically means halal meat. One of the requirements for meat to be halal is to slaughter the meat in the name of God. So, even though these respondents are aware of halal, they do not have an adequate understanding of halal principles. Based on the statements above it can be concluded that almost all respondents have the good perception and good halal food knowledge.

\section{Non-Muslim Consumers' Perception that Halal Food is Clean}

Some respondents have provided some comments and give statements as follows : "I would say [halal food] is clean, really clean" ( $\mathrm{R} 3)$.

Similar to this, other consumers describe halal food as:

"Cleanliness in food [...] Clean halal food "(R2).

Another respondent added:

"For me, halal meat, no alcohol in it, no blood inside, no dirty inside" (R4).

$\mathrm{R}(8)$ ".... I believe halal products are safe for consumption ..."

Some respondents have provided some comments and give statements as follows :

$\mathrm{R}(5)$ "... I think halal food is dirty and I often consume it ..."

R10) "... I believe halal food is not contaminated with anything ..."

A respondent (R4) gave a statement:

"My own understanding of halal-labeled food is healthy, hygienic food using no chemicals. [ . .] is not just food for Muslims "(R4).

$\mathrm{R}(6)$ "... I think halal food is very clean and good ...."

Some respondents have provided some comments and give statements as follows

"That [halal food] is clean, clean, I believe it [. . .] I will not buy non-halal food because of why, it is not as clean as it should be, and I will say no, I prefer halal food "(R3).

Based on the statements above it can be concluded that almost all respondents have the perception that halal food is clean.

\section{The Perception of non-Muslim Consumers that Halal Food is Safe}

Some respondents have provided some comments and give statements as follows :

$\mathrm{R}(6)$ "... I think halal food is very clean and good ...."

$\mathrm{R}(9)$ "... I don't think halal food is dirty and I often consume it ..."

Anothes respondents have provided some comments and give statements as follows :

R10) "... I'm sure halal food isn't contaminated by anything ...

$\mathrm{R}(5)$ "... I believe halal products are not contaminated from hazardous materials ..."

$\mathrm{R}(8)$ ".... I believe halal products are safe for consumption ..."

Based on the some statements above it can be concluded that almost all respondents have a positive perception of halal food.

\section{The Perception of non-Muslim Consumers That Halal Food is of Good Quality}


Some respondents have provided some comments and give statements as follows :

$\mathrm{R}(6)$ "... I think halal food has good quality ..."

$\mathrm{R}(7)$ "... the quality of halal food is very good compared to non-halal ..."

Another respondents have provided some comments and give statements as follows :

$\mathrm{R}(5)$ "... I think the raw material is quality ....."

$\mathrm{R}(9)$ "... quality halal products, I have no doubt ...."

R10) "... I'm sure good quality halal food ..."

"I can understand that [halal] is like a sign that shows that this food has been checked for consumers. That is, there is no blood in it and there is no survival pig "(R4).

Based on the statements above it can be concluded that almost all respondents have the perception that halal food is good quality.

\section{Non-Muslim Consumers' Perception That Halal Food Production is a Hygienic}

Some respondents have provided some comments and give statements as follows :

$\mathrm{R}(6)$ "... the process of making halal food is very hygienic ...."

$\mathrm{R}(7)$ "... I think halal food production sites are very clean ..."

Some respondents have provided some comments and give statements as follows :

$\mathrm{R}(8)$ ".... I'm sure halal food is produced according to hygiene standards ....."

$\mathrm{R}(9)$ "... the process of producing halal products is controlled and clean ...."

Some respondents have provided some comments and give statements as follows :

$\mathrm{R}(5)$ "... I believe the production process of halal products is according to the standard ...."

From the comments above, it seems that consumer awareness of halal is also related to halal food products that do not contain alcohol and which are considered unhygienic. Related to the theme of purity and cleanliness, one of the respondents said:

"I think, if I buy halal food it helps me not to consume alcohol, it also helps me not to consume blood in the meat, it also helps me not to consume dirty food in food" (R4).

Based on the statements above it can be concluded that almost all respondents have the perception that halal food is clean, safe to eat, hygienically produced, of good quality.

\section{Purchase Interest of non-Muslim Consumers on Halal Food}

Some respondents have provided some comments and give statements as follows :

"I really got halal food. I will not take anything that is not lawful. Knowing it is not lawful, I will not consume it "(Rl).

$\mathrm{R}(9)$ "... sometimes I recommend families to buy halal food ..."

$\mathrm{R} 10)$ "..every thing I shop for is halal food ..."

Another respondent introduced why he bought halal food instead of non-halal food (Haram). He stated that: "I will not buy food that is not labeled halal because why, it is not clean, not hygienic and does not contain harmful chemicals as it should, and prefers halal food" (R3).

"At the location where I grew up [. . .] We don't know who killed the pig; who slaughtered the chicken; who slaughtered anything; and now in case of halal food, you believe the person who is slaughtering, you have clear awareness of who has touched that food, who made the food or who served and prepared the food "(R2).

Another respondents believe in the halal food process and they believe that it is safe food. A respondent stated that:

"We do not buy halal food because it is called halal; we buy halal food because we think that halal food goes through what is written in the Bible too "(R4).

$\mathrm{R}(6)$ "... I prefer to buy halal food over non-halal food ..."

"If I buy meat at a non-halal store and I buy the same meat at a Muslim halal food store, at a non-halal store I don't believe, I'm not sure, because they don't have process of tracking down everyone who does that, but their halal food has process, they can check where it came from to the store, that's why we believe "(R4).

This is further proven, when respondents state that:

"There is a big difference between non-halal food and halal food because I believe in one thing, I believe, blessed, because blessed I like it" (R3). 
R (7) "... I often buy halal food ..."

$\mathrm{R}(8)$ ".... I prefer to buy halal food ....."

For them, food produced by following halal method is blessed. With regard to the difference between halal and non-halal food products, one consumer respondent stated:

"In the Muslim world, they organize, they examine and give it the name halal. Halal food is meaningful. It was inspected from the factory, and coming to the store only I believe, that's halal. I know this chicken has been slaughtered, this cow has been slaughtered and the blood is down, and I can eating this food is halal, so I can believe that marks the name". (R4).

Some respondents of non-Muslim consumer states that "When I start now choosing halal food, I see that it is healthier, more professional, has things like that." (R2). "I like to buy and eat halal food [. . .] Clean, hygienic I often buy "'(CR3).

The statement above shows that respondents want perceived benefits of halal food that is hygienic clean, therefore they buy and consume halal food. The majority of respondents are aware of benefits the halal food products.

\section{DISCUSSION}

Based on the statements above it can be concluded that almost all respondents have the perception that halal food is clean, safe to eat, hygienically produced, of good quality and they have a high interest in buying halal food.

\section{Non-Muslim Consumer Knowledge about Halal Food}

Based on the statements above it can be concluded that almost all respondents have the good perception and good halal food knowledge. This result is similar with Mnela (2009) who found that respondents chose halal food products over halal food products because they believed in halal products, especially process of slaughtering animals. Because it's far more ethical. These results are in accordance with the findings of Hamdan et al. (2013), Saad (2010), Mnela (2009). In this study, respondents were aware of how to slaughter animals and they consciously tracked these products. This is because non-Muslim consumers are becoming more aware about food and drinks. This is lawful from the initial step of making it to the last step. Thus, respondents believe in halal traceability and logistics. As such, they have confidence in management of halal food supply chains. As a result, this evidence confirms literature on quality and fresh food and consumer concerns about food safety standards (Cutler, 2007; Farm and Jacoby, 2005), also validity of halal food products (Thomas et al., 2017). In this study, respectively Muslim consumers point to the fact that meaning of halal food products is extended to halal food process as well. According to previous research, this is true. All respondents interviewed in this study believed that halal food was processed. Majority respondents have an awareness of buying halal food because halal food product manufacturers observe process of making halal food. As they know who made this product, how did they make it, and where did it come from? The proof is in accordance with research conducted by (Hamdanet al., 2013). In addition, this study agrees with what is found in the literature (Farmdan Jacoby, 2005; Hernández and Seehawer, 2002). Interestingly, another non-Muslim consumer stated that he had faith that halal food was blessed. Therefore, concept of halal was expanded beyond mere trademark, it became a spiritual image.

\section{Non-Muslim Consumers' Perception that Halal Food is Clean}

Based on the statements it can be concluded that almost all respondents have the perception that halal food is clean. Most respondents have chosen to consume halal food products because they consider that halal food is a healthy choice. This is in line with findings in the literature (Aziz and Chok, 2013; Golnaz et al., 2012; Haque et al., 2015). This confirms the study by Rezai et al. (2012) who found that while consumers are aware of halal they do not need to understand it. The halal food requires that halal food be prepared in the most hygienic manner, produced cleanly and using halal ingredients to meet food safety standards. This research showed what respondents knew about halal food products. In addition, it has identified respondents' awareness to buy halal food products. According to the research findings, respondents focus on consumption of halal food products due to increasing concerns about contaminated and unhealthy foods. This is consistent with the results of research conducted by (Zailani et al., 2015). In addition, consumer awareness of halal can influence their decision to buy and consume food products labeled as halal. It seems that among the respondents in this study linking halal with product trust, safety, quality and cleanliness. This confirms what other studies have (Aslan, 2016) found that concept of halal is well connected, healthy, safe and of high quality assessment. According to Nastasha (2015) 
and Teng et al. (2013), awareness of the benefits of halal food products provides additional guarantees for food safety and quality. The current study found that respondents were aware of the benefits derived from consuming halal food products.

\section{The Perception of non-Muslim Consumers that Halal Food is Safe}

Most respondents have chosen to consume halal food products because they consider that halal food is a safe choice. This is in line with findings in the literature (Aziz and Chok, 2013; Golnaz et al., 2012; Haque et al., 2015). This confirms the study by Rezai et al. (2012) who found that while consumers are aware of halal they do not need to understand it. The halal food requires that halal food be prepared in the most hygienic manner, produced cleanly and using halal ingredients to meet food safety standards. (Aslan, 2016) found that concept of halal is well connected, healthy, safe and of high quality assessment. Like the previous respondent who confirmed halal relationship with cleanliness and cleanliness. Awareness of benefits the halal food helps consumers to consume halal food, which they consider healthy according to research conducted by Aziz and Chok (2013), Golnaz et al. (2010), Golnaz et al. (2012) and Toong et al. (2015). In addition, one respondent gave an indication that non-Muslim consumers are looking for halal food products because they believe that food is safe and clean. Consumers want halal and quality food (Farm and Jacoby, 2005; Hernández and Seehawer, 2002) and understand process of producing halal food products. This is because they are very concerned about food safety (Golnaz et al., 2010; Lee et al., 2016). On the one hand, consumers have awareness and trust in food products that are produced based on halal requirements (Aziz and Chok, 2013).

\section{Non-Muslim Consumers' Perception That Halal Food Production is a Hygienic}

Based on the statements above it can be concluded that almost all respondents have the good perception and halal food is hygienic .This statement shows that respondents chose to consume halal food because he felt that they were getting pure and healthy food products. Armitstead (1998) shows that consumer awareness of food and health problems has increased. This involves all consumers whether Christian, Jewish, Hindu or Muslim. This confirms what was reported by the Islamic Food and Nutrition Council of America (2009) focus on foods that are healthy and not contaminated. Halal food comes from foods that can be categorized, safe and harmless. Cleanliness is an important quality for getting halal food products. This study shows that process of preparing halal food products follows clean and hygienic production. This finding is consistent with the findings of Abdullah (2006), Golnaz et al. (2010) and Marzuki et al. (2012). Halal food products seem to offer greater benefits. Burgmann (2007) found that halal food is cleaner, healthier, and tastier. In addition, this finding is consistent with the findings of Golnaz et al. (2010) which states that consumers are aware the benefits of halal method of slaughtering animals and food safety. It also helps consumers avoid consumption of contaminated food. The study found that respondents were looking for halal products, which they believed were safe, healthy and good for consumption.

\section{Purchase Interest of non-Muslim Consumers on Halal Food}

Based on the statements above it can be concluded that almost all respondents have the good perception All respondents stated the reasons for choosing halal food products rather than choosing non-halal food products. Yunus et al. (2014) explains that awareness of halal helps Muslim consumers to have a clearer picture and then make a purchasing decision, which is in harmony with their preferences and beliefs. The above respondents have confidence that halal is not a fair name, but halal food lies in the rules of the Bible, like halal food produced under same direction as the Bible. For example, buying halal food from Muslim supermarkets provides peace of mind and guarantees that products are produced in a safe manner. Hamdan et al. (2013) found that Muslim consumers made purchasing decisions according to their awareness of processed food products and not by looking for halal-labeled packaging. Some respondents did not buy halal food products because of their names; they buy it because they are aware of manufacturing process. This is because consumers believe that halal food products track more stringent quality and safety standards than non-halal products (Cutler, 2007). It is clear that process of producing halal food products is more easily recognized than process of producing halal food products. One respondent gave a reason why the trust to buy halal food products. His belief in halal food products comes from his awareness of processes involved in producing halal food products

The results of this study found that consumers have different ways in connection with consumer awareness halal food process. According to Saad (2010), the term halal is not referred to as a business name but rather as a sign to indicate that products carrying this name are free from pork, carnivorous animals, animals that 
die before slaughter, animals do not slaughter in the name of God). This is consistent with research conducted by Hamdan et al. (2013). It also shows that process of preparing halal food products follows a clean and hygienic production process. Process of producing halal food products is easier to trace than process of producing non-halal food products. Respondents from this study were aware of animal slaughter method and realized that it was very easy to trace product. Thus, respondents believe in halal and logistical searches. As a result, this confirms literature on quality and fresh food consumer concerns about food safety standards for example (Cutler, 2007; Farm and Jacoby, 2005; Hernández and Seehawer, 2002). All respondents stated that they understood about halal food products expanded to the halal food process too. This is because the belief in halal food products comes from their awareness of processes involved in producing halal food products.

According to Abdullah (2006), the level of awareness is influenced by the quality of information available and access to that information. This agrees with what the Islamic Food and Nutrition Council of America (2009) reported that focus on halal food is to be healthy and not contaminated. Because consumers before deciding to buy halal food products, they must know some information related to food products that they want to buy. In addition, consumers want to know the answers to questions such as, where do these food products come from, who are the producers of the products, how are they made? (Hernández and Seehawer, 2002). Respondents from this study feel halal food with confidence, where they believe that halal food products are healthy and clean. Halal food has a good rating, healthy, safe, hygienic and high quality (Aslan, 2016). All statements by some non-Muslim consumer respondents are in accordance with the findings of research conducted by Aziz and Chok (2013), Mohamed Elias et al. (2016), Lee et al. (2016) and Yunus et al. (2014), shows that the level of awareness of halal food is proven in many aspects of halal food including its benefits, hygienic processes and cleanliness.

Halal food is a major concern for Muslim and non-Muslim consumers. This is because cleanliness and cleanliness (Marzuki et al., 2012). In this study it was found that each respondent has a high awareness of halal. In addition, non-Muslim consumers pursue advantages and disadvantages of halal food products when they consume them. This supports research by Mnela (2009) and Ireland and Rajabzadeh (2011). Some respondents commented that having halal food products is acceptable to achieve peace of mind. The current research found that awareness of halal food plays an important role in awareness and understanding of health and safety. This is consistent with the results found in the literature (Golnazet al., 2010; Lee et al., 2016). He also found that level of awareness was the most important factor influencing consumers' choices to buy halal food products, which was in accordance with the results found in the research of Hamdan et al. (2013). Respondents were more aware of importance consuming halal food. This agrees with Man and Sazili (2010). Halal food is beneficial for non-Muslims, and is accepted as a quality system throughout the world (Marzuki et al., 2012).

\section{CONCLUSION}

This study concludes that the majority of non-Muslim consumer respondents have good knowledge and perception of halal foods that are hygienic, clean and safe to produce safely. Most respondents of non-Muslim consumers also have a high interest in buying packaged food products labeled as halal. This study found that respondents of non-Muslim consumers in Indonesia had awareness and positive perceptions of halal food, including its benefits and production processes involved in producing these foods. The study also concluded that halal is not just a commercial name used as a trademark of food products on the market. However, halal also has several dimensions as an image or sign of health and cleanliness. With regard to psychological aspects, halal is considered as a sign of trust, comfort and security. This gives consumers peace of mind when they consume food products that carry the halal label. Based on the results obtained from this study, awareness of identifying as a key factor influences the intention to buy halal food products. Respondents seemed to understand some information relating to halal food products. They realize benefits and advantages of halal labeled food products. Some of the benefits of doing this research, namely as an additional reference to gain knowledge about the Indonesia halal food industry. For food producers who have not yet carried out halal certification on their products, they should immediately do the certification, because Muslim and non-Muslim consumers provide a positive perception of halal products. From this study some information about respondents in Indonesia was known, especially those related to the level of awareness, understanding and attitude towards purchase of halallabeled food products. Limitation in the study was that the small sample size was chosen for this study. Another limitation is that, research is only conducted in the city of Indonesia. Further studies on other halal segments 
such as cosmetics and medicines, which can improve the overall image of halal products in Indonesia and other regions.

\section{REFERENCES}

[1] Abd Rahman, A., Asrarhaghighi, E. and Abd Rahman, S. (2015), "Consumers and halal cosmetic products: knowledge, religiosity, attitude and intention”, Journal of Islamic Marketing, Vol. 6 No. 1, pp. 148-163.

[2] Abdullah, A.N. (2006), "Perception and awareness among food manufacturers and marketers on halal food in the klang valley", (Master thesis), University Putra Malaysia.

[3] Abdul-Razzaq, S. (2016), "Halal, New Zealand! An exploratory study into the halal friendliness of accommodation providers in New Zealand", Master thesis, Department of Management, Marketing and Entrepreneurship, University of Canterbury, New Zealand.

[4] Abraham, V. (2018), “Christian consumers campaign against Halaal”, [Online] News24, available at: www.news24.com/SouthAfrica/News/christians-war-on-halaal-20180401-2 (accessed 2 April 2018).

[5] Africa Muslim Population (2016), available at: www.muslimpopulation.com/africa. South African.

[6] Alhojailan, M.I. (2012), “Thematic analysis: a critical review of its process and evaluation", West East Journal of Social Sciences, Vol. 1 No. 1, pp. 39-47.

[7] Ali, H. (2018), "Overview of the global halal industry and halal tourism", available at: https://islamicmarkets.com/articles/overviewof-the-global-halal-industry-and-halal-tourism-1 (accessed 28 December 2018).

[8] Armitstead, A. (1998), "The National Health Survey-consumer attitudes to health and food”, Nutrition Food Science, Vol. 98 No. 2, pp. 95-98.

[9] Aslan, D. (2016), "Measuring halal awareness at Bingol city", Journal of Social Sciences (COES\&RJ-JSS), Vol. 5 No. 3, pp. $340-355$.

[10] Asbari, M., Santoso, P., \& Purwanto, A. (2019). Pengaruh Kepemimpinan dan Budaya Organisasi Terhadap Perilaku Kerja Inovatif Pada Industri 4.0. JIM UPB (Jurnal Ilmiah Manajemen Universitas Putera Batam), 8(1), 7-15. doi: https://doi.org/10.33884/jimupb.v8i1.1562

[11] Asbari, M., Santoso, P., \& Purwanto, A. (2019). Pengaruh Iklim Organisasi dan Kepemimpinan Transformasional Terhadap Produktivitas Kerja Inovatif Pada Industri Manufaktur di Pati Jawa Tengah. Jurnal Produktivitas Universitas Muhammadiyah Pontianak, 7(1 2020), 62-69. doi: DOI : 10.29406/jpr.v7i1.1797

[12] Aziz, Y.A. and Chok, N.V. (2013), "The role of halal awareness, halal certification, and marketing components in determining halal purchase intention among non-Muslims in Malaysia: a structural equation modeling approach", Journal of International Food and Agribusiness Marketing, Vol. 25 No. 1, pp. 1-23.

[13] Bamba, A., Talek, Y. and Kaba, A.M. (2017), "Halal food in multi African society and Muslim Christian relations formation: a strategic vision in political and economic dimension”, Humanities and Social Sciences Review, Vol. 7 No. 1, pp. 81-94.

[14] Bashir, A.M. (2018), "Halal foods: South African Christian consumers' concerns”, Annual Review of Islam in Africa (ARIA), Vol. 4 No. 15 , pp. 114-117.

[15] Bashir, A.M., Bayat, A., Olutuase, S.O. and Abdul Latiff, Z. (2018), "Factors affecting consumers' intention towards purchasing halal food in South Africa: a structural equation modelling", Journal of Food Products Marketing, Vol. 25 No. 1, pp. 26-48, doi: 10.1080/10454446. 2018.1452813.

[16] Bernard, H.R. (2002), Research Methods in Anthropology: Qualitative and Quantitative Methods, 3rd ed., Altamira Press, Walnut Creek, CA.

[17] Berry, B. (2008), "Global halal food market brief”, Government of Canada, Agriculture and Agri-food Canada, Ottawa, available at: http://ats.agr.gc.ca/afr/4491-eng.pdf (accessed 15 January 2016).

[18] Braun, V. and Clarke, V. (2006), "Using thematic analysis in psychology", Qualitative Research in Psychology, Vol. 3 No. 2, pp. 77101.

[19] Burgmann, T. (2007), "Growing Muslim population pushing companies to produce products they can eat", The Star, available at: www.thestar.com/Business/article/238551

[20] Creswell, J.W. (2007), Qualitative Inquiry and Research Design. Choosing among Five Approaches, Sage Publications, Los Angeles. 
[21] Creswell, J.W. (2009), Research Design: Qualitative, Quantitative, and Mixed Methods Approaches, 3rd ed., SAGE Publications, Incorporated, Los Angeles.

[22] Creswell, J.W. (2013), Qualitative Inquiry and Research Design: Choosing among Five Approaches, 3rd ed., Sage, Thousand Oaks, CA.

[23] Crosthwaite, C. (2010), "Managerial leadership competencies of heads of departments: a case study of higher educational institutions in Kerala, India", (Doctoral dissertation), University of Southern, Queensland.

[24] Cutler, T.R. (2007), "Food safety drives growth in kosher and halal foods", International Food Safety and Quality Network, No. 201, available at: www.Trcutlerinc.Com/IFSQN205

[25] De Vos, A., Strydom, H., Fouche, C., B. and Delport, C.S.L. (2011), Research at Grass Roots: For the Social Sciences and Human Service Professions, 4th ed., Van Schaik, Pretoria.

[26] Elasrag, H. (2016), Halal Industry: Key Challenges and Opportunities, MPRA Paper No. 69631, 22 February 2016, UTC, available at: https://mpra.ub.uni-muenchen.de/69631/ (accessed 10 October 2017).

[27] Farm, S.S. and Jacoby, L. (2005), Feasibility of Marketing Traditionally Slaughtered and Processed Meat to Economically and Culturally Diverse Families, Food Markets and Restaurants, Department of Agriculture, Trade and Consumer Protection, WI.

[28] Frost, N. (2011), Qualitative Research Methods in Psychology: From Core to Combined Approaches, McGraw-Hill Education, UK.

[29] Fuseini, A., Wotton, S.B., Knowles, T.G. and Hadley, P.J. (2017), "Halal meat fraud and safety issues in the UK: a review in the context of the European union”, Food Ethics, Vol. 1 No. 2, pp. 127-142.

[30] Golnaz, R., Mohamed, Z., Shamsudin, M. and Chiew, (2012), "Non-Muslim consumers' understanding of halal principles in Malaysia”, Journal of Islamic Marketing, Vol. 3 No. 1, pp. 35-46.

[31] Golnaz, R., Zainalabidin, M., Mad Nasir, S. and Eddie Chiew, F.C. (2010), “Non-Muslims' awareness of halal principles and related food products in Malaysia", International Food Research Journal, Vol. 17, pp. 667-674.

[32] Guest, G., Bunce, A. and Johnson, L. (2006), "How many interviews are enough? An experiment with data saturation and variability", Field Methods, Vol. 18 No. 1, pp. 59-82.

[33] Guetterman, T. (2015), "Descriptions of sampling practices within five approaches to qualitative research in education and the health sciences", Educational Psychology Papers and Publications, Vol. 16 No. 2, Art. 25, available at: http://nbnresolving.de/urn:nbn:de:0114-fqs1502256

[34] Halal Research Council (2010), “The global market potential of halal”, International Conference and Expo on Halal Industry Lahore, Pakistan, available at: Repository.salaamgateway.com (accessed 5 July 2017).

[35] Hamdan, H., Issa, Z.M., Abu, N. and Jusoff, K. (2013), "Purchasing decisions among Muslim consumers of processed halal food products", Journal of Food Products Marketing, Vol. 19 No. 1, pp. 54-61.

[36] Haque, A., Sarwar, A., Yasmin, F., Tarofder, K. and Hossain, M. (2015), "Non-Muslim consumers' perception toward purchasing halal food products in Malaysia”, Journal of Islamic Marketing, Vol. 6 No. 1, pp. 133-147.

[37] Hernández, J.M. and Seehawer, J. (2002), “Consumer survey: meat hygiene a higher priority than price”, Poultry International, Vol. 1 No. 1, pp. 39-47.

[38] Ireland, J. and Rajabzadeh, S.A. (2011), "UAE consumer concerns about halal products", Journal of Islamic Marketing, Vol. 2 No. 3, pp. 274-283.

[39] Islamic Food and Nutrition Council of America (2009)I, "FANCA", available at: www.ifanca.org/newsletter/2009_03.htm

[40] Ismail, I., Abdullah, N.A.N., Ahmad, Z. and Sidek, N.L. (2018), "Halal principles and halal purchase intention among Muslim consumers", Proceedings of the 3rd International Halal Conference (INHAC 2016), Springer, Singapore, pp. 131-138.

[41] Ismoyowati, D. (2015), "Halal food marketing: a case study on consumer behavior of chicken-based processed food consumption in central part of Java, Indonesia”, Agriculture and Agricultural Science Procedia, Vol. 3, pp. 169-172. 
[42] Khan, M.I. and Haleem, A. (2016), "Understanding halal and halal certification and accreditation system, a brief review", Saudi Journal of Business and Management Studies, Vol. 1 No. 1, pp. 32-42

[43] Krishnan, S., Aderis, M.H.H.M., Azman, M.N. and Kamaluddin, M.N.A. (2017), "Halal food: study on Non-Muslim acceptance", American Journal of Economics, Vol. 7 No. 1, pp. 41-45.

[44] Krysik, J.L. and Finn, J. (2010), Research for Effective Social Work Practice, 2nd ed., Routledge, New York, NY.

[45] Lee, S.H., Siong, K.C., Lee, K.S. and Kim, H.S. (2016), "Non-Muslim customers' purchase intention on halal food products in Malaysia”, Culinary Science and Hospitality Research, Vol. 22 No. 1, pp. 108-116.

[46] Macdonald, E.K. and Sharp, B.M. (2000), "Brand awareness effects on consumer decision making for a common, repeat purchase product”, Journal of Business Research, Vol. 48 No. 1, pp. 5-15.

[47] Majid, M.A.A., Abidin, I.H.Z., Majid, H.A.M.A. and Chik, C.T. (2015), "Issues of halal food implementation in Malaysia", Journal of Applied Environmental and Biological Sciences, Vol. 5 No. 6S, pp. 50-56.

[48] Man, Y.B.C. and Sazili, A.Q. (2010), "Food production from the halal perspective", Handbook of Poultry Science and Technology, pp. 183-215.

[49] Marzuki, S.Z.S., Hall, C.M. and Ballantine, P.W. (2012), "Restaurant manager and halal certification in Malaysia", Journal of Foodservice Business Research, Vol. 15 No. 2, pp. 195-214.

[50] Mathew, V.N., Amir Abdullah, A.M. and Mohamad Ismail, S.N. (2014), "Acceptance on halal hood among non-Muslim consumers", Procedia - Social and Behavioral Sciences, Vol. 121 No. 2014, pp. 262-271.

[51] Mnela, M. (2009), "Malawi Non-Muslims prefer halal food", Retrieved from Portal Info Halal IPIJ, available at: http://halal.ipij.info/modules/AMS/print.php?storyid=2

[52] Mohamed Elias, E. Othman, S.N. and Mohd Saifudin, A. (2016), Halal Awareness and Knowledge Among Muslim's Student Entrepreneurship Program: A Preliminary Study, 2nd International Conference on Global Social Entrepreneurship (2nd ICoGBSE2016), Koh Samui, 13-14 March.

[53] Mohamed, Z., Shamsudin, M.N. and Rezai, G. (2013), "The effect of possessing information about halal logo on consumer confidence in Malaysia", Journal of International Food and Agribusiness Marketing, Vol. 25 No. 1, pp. 73-86.

[54] Nastasha, N. (2015), A Study of the Relationship between Attitude, Subjective Norms, and Perceived Behavioural Control of NonMuslim Consumers' towards Intention to Purchase Halal Food Products in Malaysia, Social Science Electronic Publishing, pp. 1-8, available at: http://dx.doi.org/10.2139/ssrn.2697898 (accessed 14 January 2019).।

[55] Purwanto, A.,Hutagalung,L.,Yanthy,.E.,(2020). FOOD SAFETY MANAGEMENT LEADERSHIP STYLE: TRANSFORMATIONAL OR TRANSACTIONAL? Jurnal Ekonomi Manajemen.14(2).171-182.

[56] https://doi.org/10.30650/jem.v14i1.1288

[57] Purwanto, A., Asbari, M., \& Santoso, P.(2019).Pengaruh Kompetensi, Motivasi, Kepemimpinan, Komitmen dan Budaya Kerja Sistem Manajemen Integrasi ISO 9001, ISO 14000 dan ISO 45001 Pada Industri Otomotif. Jurnal Produktivitas Universitas Muhammadiyah Pontianak, 6(2),158-166. DOI: http://dx.doi.org/10.29406/jpr.v6i2.1798

[58] Purwanto, A., Asbari, M., \& Santoso, P. (2020). Effect of Integrated Management System of ISO 9001:2015 and ISO $22000: 2018$ Implementation To Packaging Industries Quality Performance at Banten Indonesia. Jurnal Ilmiah MEA (Manajemen, Ekonomi, \& Akuntansi), 4(1), 17-31. https://doi.org/10.31955/mea.vol4.iss1.pp17-31

[59] Salaam Gateway (2017), "Report: free zones outlook. shaping the growth of the Islamic economy.

[60] featured report", available at: www.salaamgateway.com (accessed 10 March 2017).

[61] Smith, P.S. (2012), “South Africa: the halal Kingdom”, available at: http://gulfbusiness.com/south-africa-the-halal-kingdom.

[62] Talib, H.A. and Ali, K.A.M. (2009), “An overview of Malaysian food industry: the opportunity and quality aspects”, Pakistan Journal of Nutrition, Vol. 8 No. 5, pp. 507-517.

[63] Teng, P.K. and Wan Jusoh, W.J. (2017), "Why buying halal labelled food? Understanding the spending behavior of Non - Muslim consumers in Malaysia", International Journal of Business and Management, Vol. 1 No. 2, pp. 73-80.

[64] Teng, P.K., Siong, H.K. and Mesbahi, M.M. (2013), "Awareness, recognition and intention: insights from a non-Muslim consumer survey regarding halal-labeled food products in Malaysia”, 3rd International Conference on Management Proceeding, pp. 10-11 
[65] Purwanto, A., Asbari, M., Santoso, P., Wijayanti, L., Hyun, C., sihite, O., \& Saifuddin, M. (2020). Pengaruh Gaya Kepemimpinan Partisipatif dan Otokratis Terhadap Kinerja Sistem Jaminan Halal HAS 23000 Pada Industri Makanan Kemasan. Edumaspul: Jurnal Pendidikan, 4(1), 156-179. https://doi.org/10.33487/edumaspul.v4i1.345 